\title{
Emerging proteomics biomarkers and prostate cancer burden in Africa
}

\author{
Henry A. Adeola ${ }^{1,2}$, Jonathan M. Blackburn ${ }^{2,3}$,Timothy R. Rebbeck ${ }^{4}$ and Luiz F. \\ Zerbini $^{1,2}$ \\ ${ }^{1}$ International Centre for Genetic Engineering and Biotechnology, Cape Town, South Africa \\ ${ }^{2}$ Department of Integrative Biomedical Sciences, Faculty of Health Sciences, University of Cape Town, Cape Town, South \\ Africa \\ ${ }^{3}$ Institute of Infectious Disease \& Molecular Medicine, Faculty of Health Sciences, University of Cape Town, Cape Town, South \\ Africa \\ ${ }^{4}$ Harvard T.H. Chan School of Public Health and Dana-Farber Cancer Institute, Boston, Massachusetts, USA \\ Correspondence to: Luiz F. Zerbini, email: Iviz.zerbini@icgeb.org \\ Keywords: proteomics, biomarker, prostate cancer, Africa, mass spectrometer \\ Received: November 23, $2016 \quad$ Accepted: February 27, $2017 \quad$ Published: March 25, 2017
}

Copyright: Adeola et al. This is an open-access article distributed under the terms of the Creative Commons Attribution License (CC-BY), which permits unrestricted use, distribution, and reproduction in any medium, provided the original author and source are credited.

\section{ABSTRACT}

Various biomarkers have emerged via high throughput omics-based approaches for use in diagnosis, treatment, and monitoring of prostate cancer. Many of these have yet to be demonstrated as having value in routine clinical practice. Moreover, there is a dearth of information on validation of these emerging prostate biomarkers within African cohorts, despite the huge burden and aggressiveness of prostate cancer in men of African descent. This review focusses of the global landmark achievements in prostate cancer proteomics biomarker discovery and the potential for clinical implementation of these biomarkers in Africa. Biomarker validation processes at the preclinical, translational and clinical research level are discussed here, as are the challenges and prospects for the evaluation and use of novel proteomic prostate cancer biomarkers.

\section{INTRODUCTION}

Prostate cancer ( $\mathrm{PCa}$ ) is one of the leading causes of cancer death in men globally [1]. Factors responsible for aggressive or indolent phenotypes of $\mathrm{PCa}$ are poorly understood. The chances of developing PCa significantly increases after the age of 40 years [2]. However, even without any form of therapy, PCa often runs a protracted natural history and many men die with it rather than from the disease [3]. Over a million new cases are reported annually according to the GLOBOCAN/ IARC 2012 databases; $\mathrm{PCa}$ is the fifth leading cause of cancer death in men globally, accounting for up to 307,000 deaths annually [4]. Among cancers in Africa, PCa was reported to have the highest incidence $(59,493)$, mortality $(42,802)$ and 5 year prevalence rate $(155,028)$.

This high incidence, mortality and 5-year prevalence trend is similar in sub-Saharan Africa, Southern Africa, or the Republic of South Africa. This clearly contrasts with the situation in the developed world, where high incidence and low mortality reflect the impact of early diagnosis and prompt treatment. In most situations, cases are diagnosed at advanced stages in Africa and the mortality and incidence rates are almost at par with the situation in the Western, Middle, and Eastern Africa (Figure 1A) [5]. Owing to a relatively higher level of development and infrastructure in the Republic of South Africa, $\mathrm{PCa}$ incidence is quite high compared to the rest of Africa. However, mortality rates in this region are high as well. The fact that South Africa has a high incidence rates similar to those in North America, Western Europe and Australia but a high mortality rate comparable to most other sub-Saharan African countries (Figure 1B \& 1C) suggests that despite a relatively better diagnostic infrastructure compared with other parts of Africa, limited manpower and resources has complicated the management of the huge burden of diagnosed PCa cases [5].

The current conventional regimen for $\mathrm{PCa}$ diagnosis, which includes PSA measurement, is unreliable in the diagnostic grey area of the reference ranges $(2-10 \mathrm{ng} / \mathrm{mL})$. Hence, identifying biomarkers which tally accurately with disease risk and staging, as well as providing for evidence based treatment, is key in the reduction of PCa burden in men of African descent. Although PCa may be more 
aggressive in men of African descent [6], lack of access to care and delay in diagnosis has obfuscated evidence of a biologically more aggressive disease in African descent men. Among speculated causes of aggressive PCa disease in African men, only age [7,8] and genetic factors [9, 10] are incontrovertible. Men over the age of 40 and men of African descent are at greater risk of developing PCa compared to their Caucasian counterpart. Men of Asian origin have the least risk of developing $\mathrm{PCa}$, albeit their risk has been reported to increase when they migrate to North America [11]. Few aetiologic and risk factors have been suggested to be associated with PCa development. Modifiable risk factors for $\mathrm{PCa}$ have been difficult to identify. Obesity, smoking, alcohol consumption, androgens, diet, diabetes mellitus, and hereditary factors, inter alia, have not been consistently associated with PCa etiology [11]. PCa susceptibility gene loci on 1q24-25 (HPC1), 8p22 (MSR1), 1q25 (RNASEL), and $17 \mathrm{p} 11$ (ELAC2) have been recognized by genome wide association studies (GWAS) [12,13]. Some biological pathways that have been enriched for genetic variants in PCa GWAS were JAK2, IGF-1, prolactin, and androgen signaling pathways [14]. A better understanding of the role of these putative genetic markers is needed among African men with $\mathrm{PCa}$.

\section{CURRENT DIAGNOSTIC BIOMARKERS OF PCA}

Despite the benefit that the discovery of PSA provided in $\mathrm{PCa}$ detection, it remains an imperfect biomarker and there is room to add omics-based biomarkers to improve $\mathrm{PCa}$ detection. A number of cancerrelated biomarkers of $\mathrm{PCa}$ have been identified that may play a role in early $\mathrm{PCa}$ detection or prognosis, including: PTEN, PI3K, PCA7 gene panel, PSGR, MME, PSCA, PCA3, TMPRSS2-ERG gene fusion, CD98, EPCA, CD276, prostate-specific membrane antigen (PSMA), caveolin-1, EN-1, and annexin A3 [15].

\section{Serum markers}

Acid Phosphatase (ACPP) is one of the oldest biomarkers used for $\mathrm{PCa}$ diagnosis in serum, however the drawback of this biomarker is that ACPP is expressed by both normal and malignant prostatic tissues, as well as extraprostatic tissues [16]. Prostate-Specific Antigen (PSA), also known as kallekrein 3 (KLK3) is the most widely used serum biomarker of $\mathrm{PCa}$ and has tremendously improved the diagnosis of PCa. PSA screening was widely adopted in the USA in early 1990s as gold standard investigation for PCa [17]. However, recent evidence indicates that PSA falls short in its diagnostic ability in the lower reference ranges (2-10ng/ $\mathrm{mL}$ ). This led to its contraindication in the USA for men greater than 75 years in 2008 [18]; and for all men in 2012 [19]. Even though highly sensitive, it is not so specific and has led to a high false positive rate, false negatives and overtreatment of PCa patients. Despite this down side to PSA, very few biomarkers are currently poised to replace PSA in clinical practice $[20,21]$. To improve the diagnostic ability of PSA, several related parameters such as PSA doubling time, PSA velocity, free-to-total PSA ratio and prostate health index (PHI) have been explored [22].

\section{Tumour markers}

Prostate cancer antigen 3 (PCA3) which is otherwise known as DD3 or differential display clone 3 is a noncoding mRNA which is found to be highly abundant in malignant prostatic tissues in comparison to benign [23, 24]. It is the most widely used non-PSA based biomarker for PCa diagnosis [25]. One limitation of PCA3 test is that it is dependent on the urinary PSA transcript expression level. TMPRSS2-ERG gene fusions (Transmembrane Protease, Serine 2- ETS fusion) are members of the ETS family of genes, and can be highly expressed in malignant prostatic tissue but not expressed in benign tissue. Emerging research evidence suggests TMPRSS2-ERG fusions are unlikely to be good predictors of PCa outcomes or aggressiveness. They are expressed in only about $50 \%$ of all PCa patients, and varies substantially by race, with African-Americans having much lower staining rates [26]. It suffers the same drawback as PCA3 in that it depends on urinary PSA transcript levels for meaningful interpretation of result. Alpha methylacyl-CoA racemase (AMACR) is a highly sensitive and specific diagnostic biomarker often used in PCa tissues. Low levels of AMACR in biopsy tissues have been associated with biochemical recurrence and PCa metastasis [27].

Emerging proteomics approaches such as mass spectrometry (MS), protein microarrays, interactomics, proteogenomics as well as posttranslational modification proteomics have also been very useful in the development of biomarkers for personalized/individualized therapy of $\mathrm{PCa}$ (Figure 2). It is plausible that interplay of various other omics-based approaches would benefit personalized PCa therapies. For example, a recently described classification of the seven possible subtypes of PCa $[28,29]$ based on TMPRSS2: ERG translocations may represent a more useful molecular classification of PCa (in terms of therapeutic options) than histologic classification. Even though these emerging biomarkers (PCA3, TMPRSS2-ERG, and AMACR) have been validated in Western populations [30, 31], fewer such studies have primarily focused on African-American or African populations [32, 33]. A few other good reviews of genomic biomarkers of $\mathrm{PCa}$ can be found elsewhere [34-36]. 
A
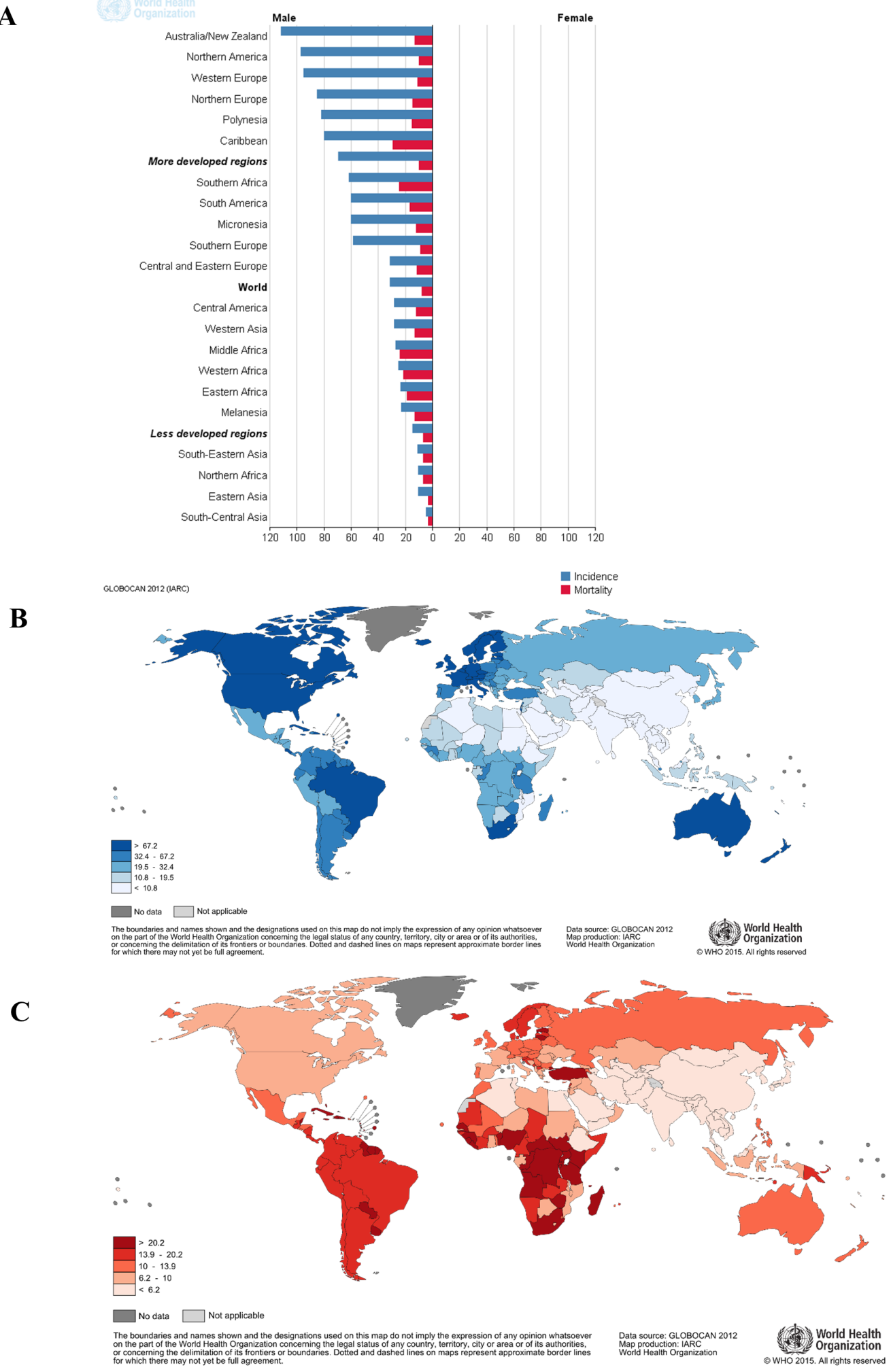

Figure 1: Global epidemiology of prostate cancer showing high burden of prostate cancer in Africa. A. A bar graph showing highest incidence and mortality of PCa in Eastern, Middle, Western and Southern regions of Africa as well as the Caribbean regions. B. and C. are maps demonstrating high incidence and mortality of prostate cancer in sub-Saharan Africa respectively. Even with a high incidence in South Africa, there is still a relatively high mortality of prostate cancer in this region in comparison to the western world. (Maps and bar graphs were adapted from the online cancer fact sheets of the WHO/IARC GLOBOCAN database 2012 at http://globocan. iarc.fr/Pages/fact_sheets_cancer.aspx). 


\section{PROSPECTS FOR PROTEOMICS IN PCA BIOMARKER RESEARCH}

The field of proteomics is a high-throughput approach to large-scale identification of the full complement of proteins in an organism, tissue, cells or body fluid. These methods are also potentially able to investigate the functional states of proteins including, posttranslational modifications, protein-protein interactions; and protein interaction with other biomolecules such as carbohydrates, lipids and other metabolites. Proteomics can provide insight into 3-D protein structures, alternative splicing events, as well as aiding genome annotation. There are variations to the proteome of a cell depending on the time point, stage of disease, diet and a host of other factors. Currently, proteomics has been employed to identify cancer-related signatures between disease and healthy cohorts of patient [37-42]. Notably, the most common proteomics methodologies are MSbased proteomics and protein microarray technology based proteomics. Using these methodologies, a gamut of proteomics biomarkers of $\mathrm{PCa}$ have already been identified [43-49], and some were demonstrated to potentially predict progression and aggressiveness of PCa [50-52]. However, successful application of omics based approaches is heavily dependent on available bioinformatics and computational biology resources, which remain limited in Africa.

\section{BIOSAMPLE SOURCES FOR PROTEOMICS BIOMARKERS OF PCA}

The preclinical phase of biomarker developed is the foundation upon which translational and clinical validation can be built. Even though tissue-based proteomics has been widely performed [53-56], body fluid-based proteomics, albeit challenging, offers a non- or minimally-invasive alternative $[57,58]$ with comparable or even superior diagnostic accuracy to tissue-based proteomics, combined with greater suitability for largescale screening or early detection methods. Potentially suitable body fluids for PCa biomarker discovery include

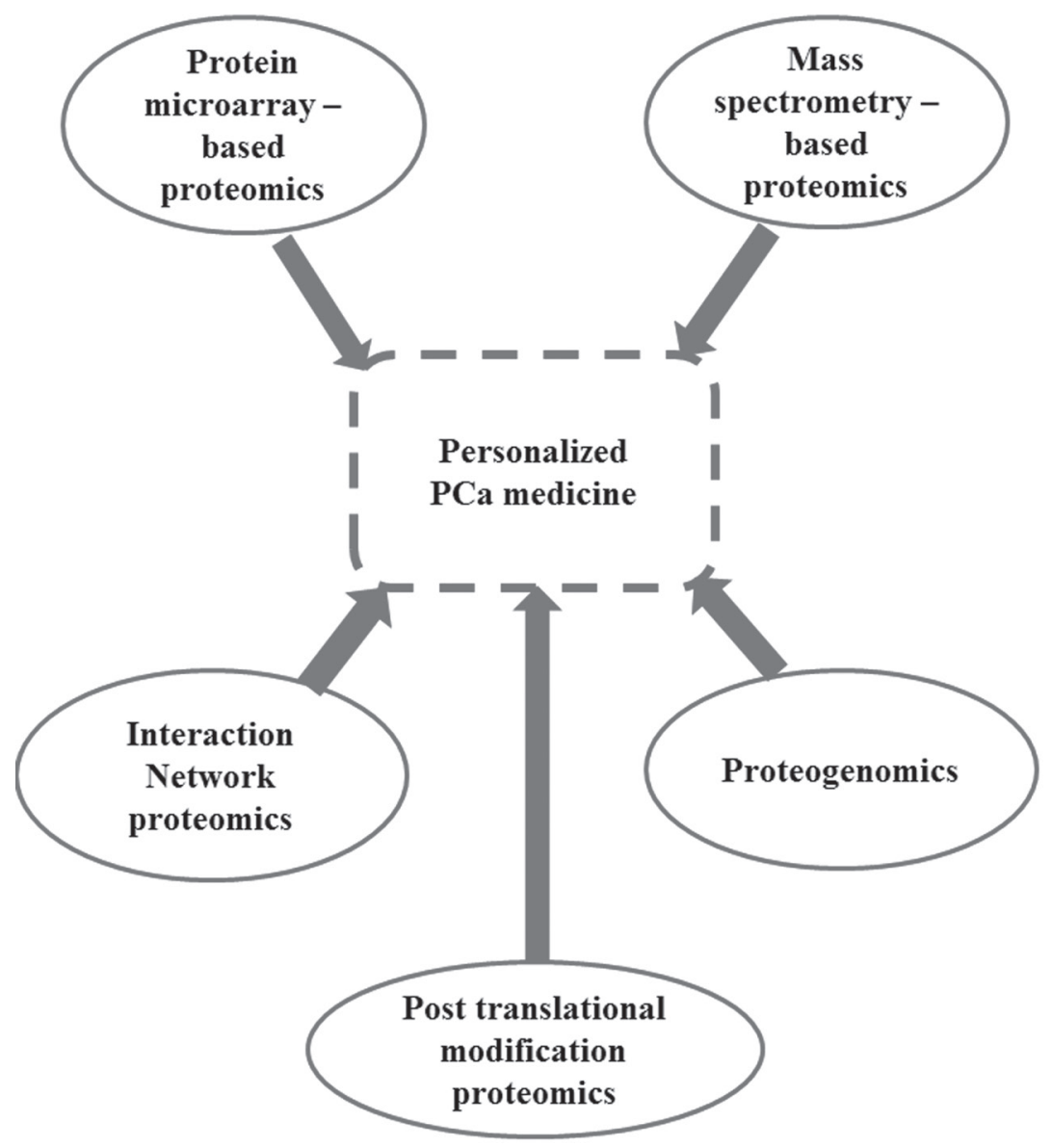

Figure 2: Role of proteomics in personalized medicine of prostate cancer. Various proteomics approaches have improved the individualization of prostate cancer therapy. An integrative approach using these proteomics methodologies would improve the identification of proteomics biomarkers of prostate cancer. As shown here, proteomics approaches such as MS-based proteomics, protein microarraysbased proteomics, interaction network proteomics, proteogenomics and well as posttranslational modification proteomics have all been of great benefit in biomarkers development for personalized/individualized therapy of Prostate cancer. 
urine, blood and semen. Liquid biopsy has been used for diagnosis of various cancer types [59-63], including PCa $[64,65]$. Additionally, this technique has been found useful in cancer patient stratification, monitoring and screening [66].

As an ultrafiltrate of blood, urine possesses analogous protein profiles as are found in peripheral blood and provides a usable catalog of proteins for interpretation of pathophysiologic events in the human body [67]. Sampling urine as compared to blood or prostatic tissue biopsy is a less invasive approach for $\mathrm{PCa}$ diagnosis and treatment monitoring. The service of skilled personnel is not required for urine sample collection. In addition to this, urine is abundantly available and permits repeated sampling [68]. Notably, the urinary proteome is less complex compared with the blood proteome and is comparatively stable, the proteins having undergone any likely proteolysis in blood or during storage in the bladder [68]. Hence, there is no need to use protease inhibitors during urine storage [68]. Despite the fact that urine is a very promising disease biomarker source, a major caveat is that its composition is variable depending on the time of the day, dietary intake and the state of health of the individual. Many urinary biomarkers of various diseases have been previously described [69], albeit only a few of these biomarkers have entered into clinical use [70-73].
Considering its extensive contact with body structures, human blood is an attractive source for biomarker discovery. Increased discohesiveness of cancerous tissues sometimes makes tumour cells more mobile and is transported in the blood stream as tumour markers. Even though limited in volume, it is the most frequently used sample for clinical diagnosis of many disease conditions. Blood samples have been used to identify biomarkers of many human diseases including: Alzheimer's disease [74], Parkinson's disease [75], breast cancer [76], preeclampsia [77], and PCa [23]. Importantly, it is also known that disease conditions such as cancer are able to stimulate humoral immune response leading to the generation of auto-antibodies [78]; and this has been demonstrated in many different human cancers, including renal [79], colorectal [80], lung [81], and PCa [82-86]. These autoantibodies generated, have potential theranostic utilities for cancer diagnosis and therapeutic vaccine target development.

\section{PROTEOMICS BIOMARKER DISCOVERY IN AFRICA}

Both urine and blood are very attractive preclinical biomarker sources for PCa in Africa. PCa proteomics has been carried out in African-American populations

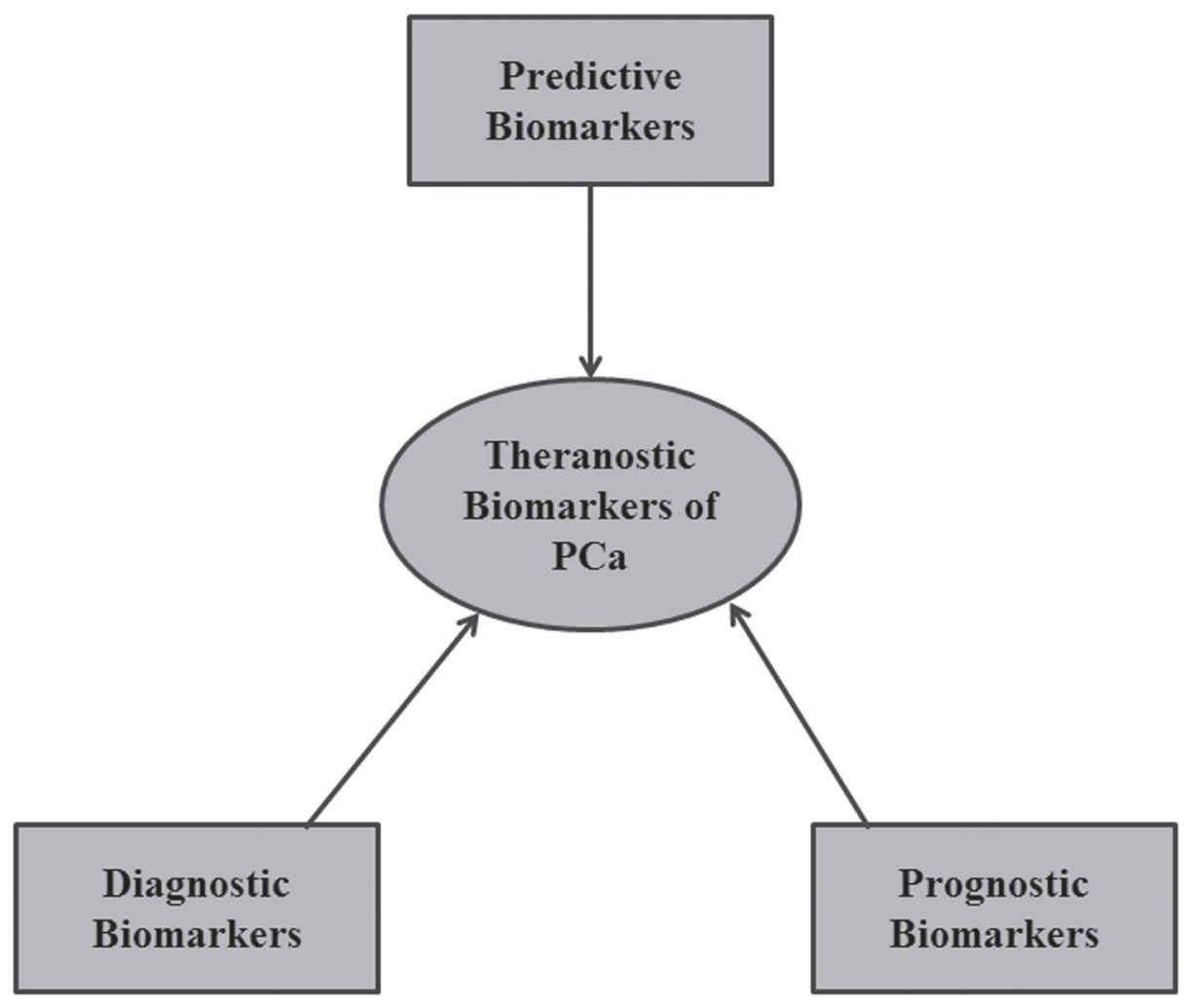

Figure 3: A theranostic approach to biomarker development. A single theranostic biomarker is capable of functioning as a diagnostic, prognostic and predictive biomarker simultaneously. 
Table 1A: List of urinary and serological proteomic biomarkers discovered in prostate cancer in a South African cohort.

\begin{tabular}{|c|c|c|c|c|}
\hline Potential PCa Proteomic biomarkers & Method used & $\begin{array}{l}\text { Biospecimen } \\
\text { used }\end{array}$ & Prevalidated & Ethnic trend \\
\hline Alpha-2-macroglobulin & MS & Urine & $\mathrm{N}$ & $\mathrm{N}$ \\
\hline Alpha-actinin-1 & MS & Urine & $\mathrm{Y}$ & $\mathrm{N}$ \\
\hline Alpha-N-acetylglucosaminidase & MS & Urine & $\mathrm{N}$ & $\mathrm{N}$ \\
\hline $\begin{array}{l}\text { Apolipoprotein A-II;Truncated apolipoprotein } \\
\text { A-II }\end{array}$ & MS & Urine & $\mathrm{N}$ & $\mathrm{N}$ \\
\hline Apolipoprotein B-100;Apolipoprotein B-48 & MS & Urine & $\mathrm{N}$ & $\mathrm{N}$ \\
\hline Apolipoprotein C-III & MS & Urine & $\mathrm{N}$ & $\mathrm{N}$ \\
\hline $\begin{array}{l}\text { Basement membrane-specific heparan sulfate } \\
\text { proteoglycan core protein }\end{array}$ & MS & Urine & $\mathrm{N}$ & $\mathrm{N}$ \\
\hline Beta-defensin 1 & MS & Urine & $\mathrm{N}$ & $\mathrm{N}$ \\
\hline C4b-binding protein alpha chain & MS & Urine & $\mathrm{N}$ & $\mathrm{N}$ \\
\hline Cadherin-11 & MS & Urine & $\mathrm{N}$ & $\mathrm{N}$ \\
\hline Carbonic anhydrase 1 & MS & Urine & $\mathrm{N}$ & $\mathrm{N}$ \\
\hline Carbonic anhydrase 2 & MS & Urine & $\mathrm{N}$ & $\mathrm{N}$ \\
\hline Carboxypeptidase $\mathrm{N}$ catalytic chain & MS & Urine & $\mathrm{Y}$ & $\mathrm{N}$ \\
\hline Cathepsin Z & MS & Urine & $\mathrm{Y}$ & $\mathrm{N}$ \\
\hline CD59 glycoprotein & MS & Urine & $\mathrm{N}$ & $\mathrm{N}$ \\
\hline Collagen alpha-1(VI) chain & MS & Urine & $\mathrm{N}$ & $\mathrm{N}$ \\
\hline Collagen alpha-1(XII) chain & MS & Urine & $\mathrm{N}$ & $\mathrm{N}$ \\
\hline Collagen alpha-2(I) chain & MS & Urine & $\mathrm{N}$ & $\mathrm{N}$ \\
\hline Collagen alpha-3(VI) chain & MS & Urine & $\mathrm{N}$ & $\mathrm{N}$ \\
\hline Complement component C8 alpha chain & MS & Urine & $\mathrm{N}$ & $\mathrm{N}$ \\
\hline Complement factor $\mathrm{H}$ & MS & Urine & $\mathrm{N}$ & $\mathrm{N}$ \\
\hline Cystatin-M & MS & Urine & $\mathrm{N}$ & $\mathrm{N}$ \\
\hline $\begin{array}{l}\text { Dihydrolipoyllysine-residue } \\
\text { succinyltransferase component of } \\
\text { 2-oxoglutarate dehydrogenase complex, } \\
\text { mitochondrial }\end{array}$ & MS & Urine & $\mathrm{N}$ & $\mathrm{N}$ \\
\hline Epididymal secretory protein E1 & MS & Urine & $\mathrm{N}$ & $\mathrm{N}$ \\
\hline Fibrillin-1 & MS & Urine & $\mathrm{N}$ & $\mathrm{N}$ \\
\hline Flavin reductase (NADPH) & MS & Urine & $\mathrm{N}$ & $\mathrm{N}$ \\
\hline Galectin-1 & MS & Urine & $\mathrm{N}$ & $\mathrm{Y}$ \\
\hline Ganglioside GM2 activator & MS & Urine & $\mathrm{N}$ & $\mathrm{N}$ \\
\hline Gastrotropin & MS & Urine & $\mathrm{N}$ & $\mathrm{Y}$ \\
\hline Glutaredoxin-1 & MS & Urine & $\mathrm{N}$ & $\mathrm{N}$ \\
\hline
\end{tabular}

$[87,88]$ but there are a limited number of studies among indigenous men of African descent. One such study identified 82 novel potential urinary biomarkers of $\mathrm{PCa}$ in a heterogeneous cohort of 45 South African patients composed of Indigenous, Mixed-Ancestry and Caucasian African PCa patients via label-free MS [89]. Among these 82 identified biomarkers, nine biomarkers were identified that suggested racial differences among the ethnicities in the cohort. Verification and prevalidation of the 82 biomarkers using both experimental 'parallel reaction monitoring' and in silico computational methods enabled identification of the top performing 12 potential biomarkers [90], ready for translation through a large scale, multiplatform and multicenter targeted proteomics validation study. Furthermore, relating to the ability of cancers to stimulate humoral immune response in the body, 41 novel potential serological autoantibody profiles have been identified in a South African PCa 
Table 1B: List of urinary and serological proteomic biomarkers discovered in prostate cancer in a South African cohort.

\begin{tabular}{|c|c|c|c|c|}
\hline Potential PCa Proteomic biomarkers & $\begin{array}{l}\text { Method } \\
\text { used }\end{array}$ & Biospecimen used & Prevalidated & Ethnic trend \\
\hline Glyceraldehyde-3-phosphate dehydrogenase & MS & Urine & $\mathrm{N}$ & $\mathrm{N}$ \\
\hline Haptoglobin & MS & Urine & $\mathrm{Y}$ & $\mathrm{N}$ \\
\hline Haptoglobin-related protein & MS & Urine & $\mathrm{N}$ & $\mathrm{N}$ \\
\hline Heat shock protein HSP 90-beta & MS & Urine & $\mathrm{N}$ & $\mathrm{Y}$ \\
\hline Hemoglobin subunit alpha & MS & Urine & $\mathrm{N}$ & $\mathrm{N}$ \\
\hline Hemoglobin subunit beta & MS & Urine & $\mathrm{N}$ & $\mathrm{N}$ \\
\hline Histone H1.5 & MS & Urine & $\mathrm{N}$ & $\mathrm{N}$ \\
\hline Ig delta chain $\mathrm{C}$ region & MS & Urine & $\mathrm{N}$ & $\mathrm{N}$ \\
\hline Ig Heavy chain V-III region ZAP & MS & Urine & $\mathrm{N}$ & Y \\
\hline Ig kappa chain V-I region BAN & MS & Urine & $\mathrm{N}$ & $\mathrm{N}$ \\
\hline Inter-alpha-trypsin inhibitor heavy chain H1 & MS & Urine & $\mathrm{N}$ & $\mathrm{N}$ \\
\hline Inter-alpha-trypsin inhibitor heavy chain $\mathrm{H} 2$ & MS & Urine & $\mathrm{N}$ & $\mathrm{N}$ \\
\hline Inter-alpha-trypsin inhibitor heavy chain $\mathrm{H} 3$ & MS & Urine & $\mathrm{N}$ & $\mathrm{N}$ \\
\hline Lactotransferrin & MS & Urine & $\mathrm{N}$ & $\mathrm{N}$ \\
\hline $\begin{array}{l}\text { Leukocyte-associated immunoglobulin-like } \\
\text { receptor } 1\end{array}$ & MS & Urine & $\mathrm{N}$ & $\mathrm{N}$ \\
\hline Lithostathine-1-alpha & MS & Urine & $\mathrm{N}$ & $\mathrm{N}$ \\
\hline Ly-6/neurotoxin-like protein 1 & MS & Urine & $\mathrm{N}$ & $\mathrm{N}$ \\
\hline Lysozyme C & MS & Urine & $\mathrm{N}$ & $\mathrm{N}$ \\
\hline $\begin{array}{l}\text { Mannan-binding lectin serine protease } 2 \mathrm{~A} \\
\text { chain }\end{array}$ & MS & Urine & $\mathrm{N}$ & $\mathrm{N}$ \\
\hline $\begin{array}{ll}\text { Mannosyl-oligosaccharide } & \text { 1,2-alpha- } \\
\text { mannosidase IA } & \end{array}$ & MS & Urine & $\mathrm{N}$ & Y \\
\hline Monocyte differentiation antigen CD14 & MS & Urine & $\mathrm{N}$ & $\mathrm{N}$ \\
\hline Myocilin & MS & Urine & $\mathrm{Y}$ & $\mathrm{Y}$ \\
\hline $\mathrm{N}$-acetylmuramoyl-L-alanine amidase & MS & Urine & $\mathrm{Y}$ & $\mathrm{N}$ \\
\hline Neutrophil gelatinase-associated lipocalin & MS & Urine & $\mathrm{N}$ & $\mathrm{N}$ \\
\hline Nidogen-1 & MS & Urine & $\mathrm{Y}$ & $\mathrm{N}$ \\
\hline Non-secretory ribonuclease & MS & Urine & $\mathrm{N}$ & $\mathrm{N}$ \\
\hline Osteopontin & MS & Urine & $\mathrm{N}$ & $\mathrm{N}$ \\
\hline Pancreatic alpha-amylase & MS & Urine & $\mathrm{N}$ & $\mathrm{N}$ \\
\hline Plasma kallikrein & MS & Urine & $\mathrm{N}$ & $\mathrm{N}$ \\
\hline Plastin-2 & MS & Urine & $\mathrm{N}$ & $\mathrm{N}$ \\
\hline $\begin{array}{lll}\text { Platelet glycoprotein } & \text { Ib } & \text { Alpha chain; } \\
\text { Glycocalicin }\end{array}$ & MS & Urine & $\mathrm{N}$ & Y \\
\hline Polyubiquitin-C & MS & Urine & $\mathrm{N}$ & $\mathrm{N}$ \\
\hline Pregnancy zone protein & MS & Urine & $\mathrm{Y}$ & $\mathrm{N}$ \\
\hline $\begin{array}{lll}\begin{array}{l}\text { Pro-epidermal } \\
\text { growth factor }\end{array} & \text { frowth } \\
\end{array}$ & MS & Urine & $\mathrm{N}$ & $\mathrm{N}$ \\
\hline Prostaglandin-H2 D-isomerase & MS & Urine & $\mathrm{N}$ & $\mathrm{N}$ \\
\hline
\end{tabular}

patient cohort $(N=67)$ [91]. These identified serological autoantibody responses could potentially be used in the construction of mini-arrays as point of care diagnostic tools as well as for therapeutic vaccine development for $\mathrm{PCa}$ in Africa. Many of these potential biomarkers have been reported in literature as being associated with other diseases, $\mathrm{PCa}$ as well as cancers in other human body organs; however, many are still yet to be described 
Table 1C: List of urinary and serological proteomic biomarkers discovered in prostate cancer in a South African cohort.

\begin{tabular}{|c|c|c|c|c|}
\hline Potential PCa Proteomic biomarkers & Method used & Biospecimen used & Prevalidated & Ethnic trend \\
\hline Prostate-specific antigen & MS & Urine & $\mathrm{Y}$ & $\mathrm{N}$ \\
\hline Prostatic acid phosphatase;PAPf39 & MS & Urine & $\mathrm{Y}$ & $\mathrm{N}$ \\
\hline proteasome inhibitor P131 subunit & MS & Urine & $\mathrm{N}$ & $\mathrm{Y}$ \\
\hline Protein S100-A9 & MS & Urine & $\mathrm{N}$ & $\mathrm{N}$ \\
\hline Ribonuclease pancreatic & MS & Urine & $\mathrm{N}$ & $\mathrm{N}$ \\
\hline Roundabout homolog 4 & MS & Urine & $\mathrm{N}$ & $\mathrm{N}$ \\
\hline Saposin-D & MS & Urine & $\mathrm{N}$ & $\mathrm{N}$ \\
\hline Serum paraoxonase/arylesterase 1 & MS & Urine & $\mathrm{N}$ & $\mathrm{N}$ \\
\hline $\begin{array}{l}\text { SH3 domain-binding glutamic acid-rich-like } \\
\text { protein } 3\end{array}$ & MS & Urine & $\mathrm{N}$ & $\mathrm{N}$ \\
\hline SLAIN motif-containing protein 1 & MS & Urine & $\mathrm{Y}$ & $\mathrm{Y}$ \\
\hline Tenascin & MS & Urine & $\mathrm{N}$ & $\mathrm{N}$ \\
\hline Trefoil factor 1 & MS & Urine & $\mathrm{N}$ & $\mathrm{N}$ \\
\hline Trefoil factor 2 & MS & Urine & $\mathrm{N}$ & $\mathrm{N}$ \\
\hline Trefoil factor 3 & MS & Urine & $\mathrm{N}$ & $\mathrm{N}$ \\
\hline Uteroglobin & MS & Urine & $\mathrm{N}$ & $\mathrm{N}$ \\
\hline Vitamin K-dependent protein S & MS & Urine & $\mathrm{Y}$ & $\mathrm{N}$ \\
\hline WAP four-disulfide core domain protein 2 & MS & Urine & $\mathrm{N}$ & $\mathrm{N}$ \\
\hline BORIS BO & CAA & Blood & $\mathrm{N}$ & $\mathrm{N}$ \\
\hline CAMEL & CAA & Blood & $\mathrm{N}$ & $\mathrm{N}$ \\
\hline CAML1 & CAA & Blood & $\mathrm{N}$ & $\mathrm{Y}$ \\
\hline CCDC33 & CAA & Blood & $\mathrm{N}$ & $\mathrm{N}$ \\
\hline CDK2 & CAA & Blood & $\mathrm{N}$ & $\mathrm{Y}$ \\
\hline CEACAM1 Isoform 1 & CAA & Blood & $\mathrm{N}$ & $\mathrm{N}$ \\
\hline COL6A1 & CAA & Blood & $\mathrm{N}$ & $\mathrm{Y}$ \\
\hline CSAG2 & CAA & Blood & $\mathrm{N}$ & $\mathrm{N}$ \\
\hline CT47.11 & CAA & Blood & $\mathrm{N}$ & $\mathrm{N}$ \\
\hline DDX53 & CAA & Blood & $\mathrm{N}$ & $\mathrm{N}$ \\
\hline DPPA4 & CAA & Blood & $\mathrm{N}$ & $\mathrm{N}$ \\
\hline EGFR & CAA & Blood & $\mathrm{N}$ & $\mathrm{N}$ \\
\hline FES & CAA & Blood & $\mathrm{N}$ & $\mathrm{N}$ \\
\hline FGFR2 & CAA & Blood & $\mathrm{N}$ & $\mathrm{N}$ \\
\hline GAGE1 & CAA & Blood & $\mathrm{N}$ & $\mathrm{N}$ \\
\hline GAGE5 & CAA & Blood & $\mathrm{N}$ & $\mathrm{N}$ \\
\hline LDHC & CAA & Blood & $\mathrm{N}$ & $\mathrm{N}$ \\
\hline
\end{tabular}

in PCa [89]. A comprehensive list which highlights the emerging potential biomarkers of $\mathrm{PCa}$ from those studies in terms of their source, methods used for their discovery and how far down the biomarker discovery pipeline they have moved, is provided in Tables 1A, 1B, 1C,1D. Even though several potential preclinical biomarkers of $\mathrm{PCa}$ have been discovered in Western studies, very few studies have identified and validated novel potential biomarkers of PCa in Africa.

\section{CURRENT APPROACHES TO PCA PROTEOMICS BIOMARKER DEVELOPMENT}

The essence of translational research in the biomarker pipeline is to create a bridge from benchderived or preclinical biomarkers to clinical utility. The clinical validation pipeline is comprised of various stringent phases through which preclinical biomarkers 
Table 1D: List of urinary and serological proteomic biomarkers discovered in prostate cancer in a South African cohort.

\begin{tabular}{|c|c|c|c|c|}
\hline $\begin{array}{l}\text { Potential PCa Proteomic } \\
\text { biomarkers }\end{array}$ & Method used & Biospecimen used & Prevalidated & Ethnic trend \\
\hline MAGEA11 & CAA & Blood & $\mathrm{N}$ & $\mathrm{N}$ \\
\hline MAGEB1 & CAA & Blood & $\mathrm{N}$ & $\mathrm{N}$ \\
\hline MAGEB5 & CAA & Blood & $\mathrm{N}$ & $\mathrm{N}$ \\
\hline MAGEB6 & CAA & Blood & $\mathrm{N}$ & $\mathrm{N}$ \\
\hline MAPK3 & CAA & Blood & $\mathrm{N}$ & \begin{tabular}{|l}
$\mathrm{Y}$ \\
\end{tabular} \\
\hline NY-ESO-1 & CAA & Blood & $\mathrm{N}$ & $\mathrm{N}$ \\
\hline OIP5 & CAA & Blood & $\mathrm{N}$ & $\mathrm{Y}$ \\
\hline p53 & CAA & Blood & $\mathrm{N}$ & $\mathrm{N}$ \\
\hline p53 C141Y & CAA & Blood & $\mathrm{N}$ & $\mathrm{N}$ \\
\hline p53 K328R & CAA & Blood & $\mathrm{N}$ & $\mathrm{N}$ \\
\hline p53 L344P & CAA & Blood & $\mathrm{N}$ & $\mathrm{N}$ \\
\hline p53 Q136X & CAA & Blood & $\mathrm{N}$ & $\mathrm{N}$ \\
\hline p53 S15A & CAA & Blood & $\mathrm{N}$ & $\mathrm{Y}$ \\
\hline p53 S392A & CAA & Blood & $\mathrm{N}$ & $\mathrm{N}$ \\
\hline p53 S46A & CAA & Blood & $\mathrm{N}$ & $\mathrm{N}$ \\
\hline p53 T18A & CAA & Blood & $\mathrm{N}$ & $\mathrm{Y}$ \\
\hline PBK & CAA & Blood & $\mathrm{N}$ & $\mathrm{Y}$ \\
\hline PRKCZ & CAA & Blood & $\mathrm{N}$ & $\mathrm{N}$ \\
\hline RAF & CAA & Blood & $\mathrm{N}$ & $\mathrm{N}$ \\
\hline ROPN1A & CAA & Blood & $\mathrm{N}$ & $\mathrm{Y}$ \\
\hline SPANXA1 & CAA & Blood & $\mathrm{N}$ & $\mathrm{N}$ \\
\hline SSX2A & CAA & Blood & $\mathrm{N}$ & $\mathrm{N}$ \\
\hline TKTL1 (Isoform a) & CAA & Blood & $\mathrm{N}$ & $\mathrm{N}$ \\
\hline ZNF165 & CAA & Blood & $\mathrm{N}$ & $\mathrm{N}$ \\
\hline
\end{tabular}

are tested before they can be certified for clinical utility. These biomarkers are applicable to various stages of PCa diagnosis and treatment as described below. Many of the currently emerging biomarkers have theranostic capabilities, implying that they possess predictive, diagnostic and prognostic potential [92-94] (Figure 3). Such double-edged "theranostic" biomarkers, which are capable of aiding diagnosis and well as serving as a means of treatment are very much needed in Africa where early diagnosis, treatment costs and patient compliance play a major role in PCa management outcome. Considering that the burgeoning biomarkers of $\mathrm{PCa}$ in the literature are poorly validated [95], more effort is needed to establish innovative ways to improve the success of emerging biomarkers through the validation phases and into clinical application.

The need for systematic validation of proteomics biomarkers and lack of standardization of validation methods among researchers [71, 96, 97] has led to the establishment of the Early Detection Research Network
(EDRN) and the Prospective Specimen Collection, Retrospective Blinded Evaluation (PRoBE) collaboration with the National Cancer Institute (NCI) [25, 98]. One important identified cause of unsuccessful biomarker validation is the lack of concordant experimental outcome from independent research groups [25]. Prensner et al therefore suggested a three-phased biomarker validation pipeline, starting with a discovery phase, followed by validation in a retrospective cohort, and then final validation in a prospective cohort [24]. Mandrekar et al emphasized that critical planning is essential in biomarker validation design and that the use of prospective randomized controlled trials as a gold standard enables a distinction between prognostic and predictive biomarkers [99]. Analytic validation, clinical qualification/validity and clinical utilization has been recommended as vital steps in the rigorous evaluation of biomarkers and surrogate endpoints in chronic diseases [72, 99].

Using these biomarker validation steps, features including high-grade prostatic intraepithelial neoplasia 
Table 2: The Early Detection Research Network (EDRN) 5-phase biomarker validation pipeline for the identification and validation of potential biomarkers for cancer control (Pepe et al 2001 [97])

\begin{tabular}{|l|l|l|}
\hline Phase & Activity & Expected outcome \\
\hline I & Preclinical exploratory phase & Promising potential biomarkers are identified \\
\hline II & Clinical assay and validation & Identification of disease establishment \\
\hline III & Retrospective longitudinal study & Preclinical detection of disease \\
\hline IV & Prospective screening & Characteristics and extent of disease \\
\hline V & $\begin{array}{l}\text { Assessment of effect of screening with biomarker on the burden of } \\
\text { disease }\end{array}$ & Cancer control \\
\hline
\end{tabular}

(HGPIN), PSA level, apoptosis and proliferation may be considered as surrogate endpoint biomarkers of $\mathrm{PCa}$ [100]. In addition, Brown et al suggested that bone-related peptides like $\mathrm{N}$ - and C-terminal peptide fragments of type I collagen, and bone-specific alkaline phosphatase can be used as endpoint biomarkers in $\mathrm{PCa}$ [101]. Despite the fact that the drug development pipeline is well established, biomarker validation pipeline is still a controversial subject among biomarker researchers. Through the efforts of the EDRN, Pepe et al have developed a 5-phased biomarker validation pathway $[97,102]$ that extends the ideas of Prensner et al [24]: The first stage is the preclinical exploratory phase where promising potential biomarkers are identified; Phase II involves clinical assay and validation to identify disease establishment; Phase III is a retrospective longitudinal study for preclinical detection of disease; Phase IV involves a prospective screening of the characteristics and extent of disease; and Phase $\mathrm{V}$ is aims at cancer control by assessing the effect of screening with biomarker on the burden of disease in the population (Table 2). Several standard guidelines for reporting and evaluating biomarker studies have emerged: reporting recommendation for tumour markers (REMARK); biospecimen reporting for improved study quality (BRISQ); minimum information about a microarray experiment (MIAME); standard for reporting diagnostic accuracy (STARD); and the level of evidence (LoE) based tumor marker guideline (TMUG) proposed by the American Society of Clinical Oncology (ASCO) in 1996 [72]. These guidelines have promoted transparency and rigour in the way biomarker discovery is being reported and evaluated; albeit most are yet to be implemented in African cancer biomarker studies.

\section{CHALLENGES AND PROSPECTS OF PCA PROTEOMICS BIOMARKER DISCOVERY IN AFRICA}

It is clear that the burden $\mathrm{PCa}$ on the African continent has increased significantly over the recent years, with the highest mortality rates reported in subSaharan Africa [6]. It has also been demonstrated that $\mathrm{PCa}$ incidence rates in African-American and West African populations differ, even though they share a common genetic ancestry [7,9]. The bases for such disease disparities are largely unknown, and it has been difficult to develop state-of-the-art research on prostate tumorigenesis and biology in Sub-Saharan Africa. Barriers to knowledge about PCa in Sub-Saharan Africa include sociocultural issues such as poor funding [102, 103], insufficient manpower [102] and skilled health personnel [104], poor access to healthcare [10], religious and cultural beliefs [105], lack of well-updated cancer registries [106], poor research and healthcare infrastructure [102, 107], low educational level [108], prevalence of infection $[109,110]$, poor governance structures and fiscal policies [111]. Although these factors are not unique to the African continent, the underlying genetic, hereditary and environmental basis of $\mathrm{PCa}$ aggressiveness in men of African descent still warrants further research.

The advent of proteomics and other high throughput omics-based technologies has highlighted the need for computational biology, as well as for state-of-theart banking of experimental biospecimens. Improper documentation and storage of biologic specimen may result in skewed biochemical inferences, histopathologic analysis and predicted therapy. Hence, a good specimen biorepository is an essential infrastructure for development of high throughput omics based personalized medicine in Africa. Most ground breaking projects in the field of molecular biology such as the Human Genome Project (HGP) [112], The Cancer Genome Atlas (TCGA) [113], Human Proteome Project (HPP) [114] and Chromosome Centric Human Proteome Project (CHPP) [115] have benefitted immensely from specimen biorepositories. However, in Africa, it is apparent that there is a limited biobanking capacity and that procedures such as fresh snap frozen tissue sampling cannot be performed in most places because liquid nitrogen is largely unavailable. Furthermore, there has traditionally been a paucity of bioinformatics infrastructure and bioinformaticians in 
Africa, although this is now being addressed through National Institutes of Health (NIH)-funded training and capacity development initiatives, such as the H3ABionet consortium. The National Cancer Institute has described a biorepository as human specimen collection including relevant data for the purpose of research, and subject to relevant processes, ethics and policies [116, 117]. Despite the gamut of biorepositories established in the Americas, Europe, Asia and Australia [118-120], very few such biobanks have been established in sub-Saharan Africa [121]. Most biorepositories in Africa are established within investigator's research group and most are yet to be standardized and centralized. Several challenges have plagued biorepository development and regulation in subSaharan Africa [121-124], albeit modest progress has been made in a few sub-Saharan African countries. Notably, the emergence of the NIH and Wellcome Trust-funded H3Africa consortium, has improved the centralization and standardization of biospecimen collection in Africa [124]. Further collaborative effort is required by clinicians and scientists to standardize and improve the development of a centralized biorepository in Africa, such that high throughput 'omics technologies can be backed by adequate research materials/resources, enabling them to play a central role in improving our current understanding of PCa in Africa.

In silico prevalidation is required in early phase of biomarkers development study [21,90], to optimize potential biomarkers prior to large scale studies. The cost implication and infrastructure needed for large scale validation of omics based biomarkers can be prohibitive [125], hence collaborative efforts such as the EDRN are necessary to achieve this goal [98]. In addition, standard validation procedures often require validated surrogate prognostic biomarkers that have been tested in multiple phase III trials [126]. Due to prohibitive costs, only important proteins or antibodies from the discovery phase would typically be validated [127]. Proteogenomic integration is thus an important multipronged approach to identify viable diagnostic and treatment signatures for PCa. For example, androgen receptors (AR) and EGFR has been identified as correlating with PCa progression using gene expression data integrated with protein interaction networks [128]. In line with an integrated proteogenomic approach, other emerging liquid biopsy biomarkers such as long non-coding RNA and exosomes holds future prospects for $\mathrm{PCa}$ [129]. Sixteen putative proteomics biomarkers of PCa validated on a well annotated tissue microarray (TMA) containing ca. 2500 PCa samples has been used to establish a prediction nomogram for $\mathrm{PCa}$ [130]. Several genomic classifiers have also emerged for clinical metastasis and biochemical recurrence, as well as for patient stratification [131]. Hitherto, most discovered biomarkers have focused on diagnostic rather than prognostic and predictive potentials [25]. As emphasized earlier, there is an urgent need for larger biorepository establishment to facilitate disease biomarker discovery and validation [25]. Emerging biomarkers such as circulating tumour cells (CTC) in blood may enable the evaluation of disease prognosis and survival [132]. Advances in PCa biomarker development has resulted in the clinical utility of laboratory tests such as Prolaris score, Oncotype Dx, Confirm MDx, Prostarix and 4K score [133]. These tests have helped to improve diagnosis of $\mathrm{PCa}$ and decipher the level of evidence (LoE) assigned for biomarker validation [134]. Urine and blood sample testing for biomarkers is a reasonable approach with high prospect for mass screening of populations for disease [135], particularly in African populations that are at greater risk of developing aggressive $\mathrm{PCa}$.

\section{CONCLUSIONS AND RE- COMMENDATIONS}

This review has demonstrated the prospects for discovery and validation of potential biomarkers in Africa. Currently available biomarkers and biomarkers sources were highlighted, as well as the application of high throughput methodologies for candidate biomarker discovery. Being a continent with a huge burden of cancer and mostly populated by low and middle income countries (LMIC), several challenges have been identified that militate against the routine application of proteomics to PCa research. The most promising urinary biomarkers which require further validation are the top 12 identified by targeted proteomics [90]; while the best serological biomarkers are the top 41 tumour associated antigens [91]. All potential urinary and serological biomarkers that demonstrated ethnic trends are also worth investigating further for potential used for personalized management of $\mathrm{PCa}$ in Africa. There is a pressing need to develop cancer research initiatives and collaborations with partners within and outside of Africa. Potential PCa biomarkers discovered in African studies requires research and systematic validation as practiced in the developed world, with urine and blood based theranostic biomarkers offering a multipronged approach to diagnosis and treatment of $\mathrm{PCa}$ in Africa. Ethnic-tailored biomarkers for PCa management are required if personalized medicine is to become a reality among African populations. Collaborative research directed towards understanding the potential role of PCa immunotherapy in African patients should also be encouraged, both locally and internationally. Importantly, diagnostic focus should be redirected towards less invasive approaches to $\mathrm{PCa}$ management, to improve early screening and intervention in Africa. It is also suggest that a centralized specimen and proteome repository should be built for $\mathrm{PCa}$ in Africa, as this would provide a resource for better research into PCa burden among men of African descent. 


\section{Abbreviations}

ASCO: American Society of Clinical Oncology; BRISQ: Biospecimen Reporting for Improved Study Quality; CHPP: Chromosome Centric Human Proteome Project; CTC: Circulating Tumour Cells; EDRN: Early Detection Research Network; GLOBOCAN: Global Cancer Statistics Database; GWAS: Genome-Wide Association Studies; HGP: Human Genome Project; HGPIN: High-Grade Prostatic Intraepithelial Neoplasia; HPP: Human Proteome Project; IARC: International Agency for Research on Cancer; LoE: Level of Evidence; MIAME: Minimum Information about a Microarray Experiment; NCI: National Cancer Institute; PCa: Prostate Cancer; PHI: Prostate Health Index; PRoBE: Prospective Specimen Collection, Retrospective Blinded Evaluation; REMARK: Reporting Recommendation for Tumour Markers; STARD: Standard for Reporting Diagnostic Accuracy; TCGA: The Cancer Genome Atlas; TMA: Tissue Microarray; TMUG: Tumor marker guideline.

\section{Author contributions}

HAA designed, prepared and revised the manuscript, figures and Table. JMB and TRR were involved in the preparation and critical intellectual revision of the paper. LFZ was involved in the design, preparation and revision of the manuscript.

\section{ACKNOWLEDGMENTS}

The authors would like to thank the International Centre for Genetic Engineering and Biotechnology (ICGEB) for funding this work.

\section{CONFLICTS OF INTEREST}

The authors declare that they have no conflict of interest.

\section{FUNDING}

HAA was a recipient of the ICGEB predoctoral fellowship. HAA thanks the South African Medical Research Council (SAMRC) for a mid-career fellowship. The funders played no role in the design or interpretation of the paper or the decision to publish.

\section{REFERENCES}

1. Fitzmaurice C, Dicker D, Pain A, Hamavid H, MoradiLakeh M, MacIntyre MF, Allen C, Hansen G, Woodbrook R, Wolfe C, Hamadeh RR, Moore A, Werdecker A, et al. The Global Burden of Cancer 2013. JAMA Oncol. 2015;
$1: 505-27$.

2. Pollock PA, Ludgate A, Wassersug RJ. In 2124, half of all men can count on developing prostate cancer. Curr Oncol. $2015 ; 22: 10-12$.

3. Ganz PA, Barry JM, Burke W, Col NF, Corso PS, Dodson E, Hammond ME, Kogan BA, Lynch CF, Newcomer L, Seifter EJ, Tooze JA, Viswanath KV, et al. NIH Stateof-the-Science Conference Statement: role of active surveillance in the management of men with localized prostate cancer. NIH Consens State Sci Statements. 2011; 28:1-27.

4. Ferlay J, Soerjomataram I, Dikshit R, Eser S, Mathers C, Rebelo M, Parkin DM, Forman D, Bray F. Cancer incidence and mortality worldwide: sources, methods and major patterns in GLOBOCAN 2012. International journal of cancer. 2015; 136:E359-386.

5. Ferlay JS, Ervik M, Dikshit R, Eser S, Mathers C, Rebelo M, Parkin DM, Forman D, Bray F. GLOBOCAN 2012 v1.0, Cancer Incidence and Mortality Worldwide. IARC CancerBase No 11 Lyon, France: International Agency for Research on Cancer; 2013.

6. Torre LA, Bray F, Siegel RL, Ferlay J, Lortet-Tieulent J, Jemal A. Global cancer statistics, 2012. CA Cancer J Clin. 2015; 65:87-108.

7. Sitas F, Parkin M, Chirenje Z, Stein L, Mqoqi N, Wabinga H. Cancers. In: Jamison DT, Feachem RG, Makgoba MW, Bos ER, Baingana FK, Hofman KJ, Rogo KO, editors. Disease and Mortality in Sub-Saharan Africa. 2nd edition. Washington (DC): World Bank; 2006. Chapter 20.

8. Jemal A, Bray F, Forman D, O'Brien M, Ferlay J, Center M, Parkin DM. Cancer burden in Africa and opportunities for prevention. Cancer. 2012; 118:4372-84.

9. Chu LW, Ritchey J, Devesa SS, Quraishi SM, Zhang H, Hsing AW. Prostate cancer incidence rates in Africa. Prostate cancer. 2011; 2011:947870.

10. Zeigler-Johnson CM, Spangler E, Jalloh M, Gueye SM, Rennert H, Rebbeck TR. Genetic susceptibility to prostate cancer in men of African descent: implications for global disparities in incidence and outcomes. Can J Urol. 2008; 15:3872-82.

11. De Marzo AM, Meeker AK, Zha S, Luo J, Nakayama M, Platz EA, Isaacs WB, Nelson WG. Human prostate cancer precursors and pathobiology. Urology. 2003; 62:55-62.

12. Alvarez-Cubero MJ, Saiz M, Martinez-Gonzalez LJ, Alvarez JC, Lorente JA, Cozar JM. Genetic analysis of the principal genes related to prostate cancer: a review. Urol Oncol. 2013; 31:1419-29.

13. Alvarez-Cubero MJ, Martinez-Gonzalez LJ, Saiz M, Carmona-Saez P, Alvarez JC, Pascual-Geler M, Lorente JA, Cozar JM. Prognostic role of genetic biomarkers in clinical progression of prostate cancer. Exp Mol Med. 2015; 47:e176.

14. Hicks C, Koganti T, Giri S, Tekere M, Ramani R, SitthiAmorn J, Vijayakumar S. Integrative genomic analysis for 
the discovery of biomarkers in prostate cancer. Biomark Insights. 2014; 9:39-51.

15. Velonas VM, Woo HH, dos Remedios CG, Assinder SJ. Current status of biomarkers for prostate cancer. Int J Mol Sci. 2013; 14:11034-60.

16. Graddis TJ, McMahan CJ, Tamman J, Page KJ, Trager JB. Prostatic acid phosphatase expression in human tissues. Int J Clin Exp Pathol. 2011; 4:295-306.

17. Jemal A, Fedewa SA, Ma J, Siegel R, Lin CC, Brawley $\mathrm{O}$, Ward EM. Prostate Cancer Incidence and PSA Testing Patterns in Relation to USPSTF Screening Recommendations. JAMA. 2015; 314:2054-61.

18. Force US, and U.S. Preventive Services Task Force. Screening for prostate cancer: U.S. Preventive Services Task Force recommendation statement. Ann Intern Med. 2008; 149:185-91.

19. Moyer VA, Force US, and U.S. Preventive Services Task Force. Screening for prostate cancer: U.S. Preventive Services Task Force recommendation statement. Ann Intern Med. 2012; 157:120-34.

20. Cary KC, Cooperberg MR. Biomarkers in prostate cancer surveillance and screening: past, present, and future. Ther Adv Urol. 2013; 5:318-29.

21. Amaro A, Esposito AI, Gallina A, Nees M, Angelini G, Albini A, Pfeffer U. Validation of proposed prostate cancer biomarkers with gene expression data: a long road to travel. Cancer Metastasis Rev. 2014; 33:657-71.

22. Huang JG, Goldenberg SL. PSA and beyond: biomarkers in prostate cancer. B C Med J. 2014; 55:334-41.

23. Dijkstra S, Mulders PF, Schalken JA. Clinical use of novel urine and blood based prostate cancer biomarkers: a review. Clin Biochem. 2014; 47:889-96.

24. Bussemakers MJ, van Bokhoven A, Verhaegh GW, Smit FP, Karthaus HF, Schalken JA, Debruyne FM, Ru N, Isaacs WB. DD3: a new prostate-specific gene, highly overexpressed in prostate cancer. Cancer Res. 1999; 59:5975-79.

25. Prensner JR, Rubin MA, Wei JT, Chinnaiyan AM. Beyond PSA: the next generation of prostate cancer biomarkers. Sci Transl Med. 2012; 4:127rv3.

26. Pettersson A, Graff RE, Bauer SR, Pitt MJ, Lis RT, Stack EC, Martin NE, Kunz L, Penney KL, Ligon AH, Suppan C, Flavin R, Sesso HD, et al. The TMPRSS2:ERG rearrangement, ERG expression, and prostate cancer outcomes: a cohort study and meta-analysis. Cancer Epidemiol Biomarkers Prev. 2012; 21:1497-509.

27. Rubin MA, Bismar TA, Andrén O, Mucci L, Kim R, Shen R, Ghosh D, Wei JT, Chinnaiyan AM, Adami HO, Kantoff PW, Johansson JE. Decreased alpha-methylacyl $\mathrm{CoA}$ racemase expression in localized prostate cancer is associated with an increased rate of biochemical recurrence and cancer-specific death. Cancer Epidemiol Biomarkers Prev. 2005; 14:1424-32.

28. Berger MF, Lawrence MS, Demichelis F, Drier Y,
Cibulskis K, Sivachenko AY, Sboner A, Esgueva R, Pflueger D, Sougnez C, Onofrio R, Carter SL, Park K, et al. The genomic complexity of primary human prostate cancer. Nature. 2011; 470:214-20.

29. Cancer Genome Atlas Research Network. The Molecular Taxonomy of Primary Prostate Cancer. Cell. 2015; 163:1011-25.

30. Wei JT, Feng Z, Partin AW, Brown E, Thompson I, Sokoll L, Chan DW, Lotan Y, Kibel AS, Busby JE, Bidair M, Lin DW, Taneja SS, et al. Can urinary PCA3 supplement PSA in the early detection of prostate cancer? J Clin Oncol. 2014; 32:4066-72.

31. Box A, Alshalalfa M, Hegazy SA, Donnelly B, Bismar TA. High alpha-methylacyl-CoA racemase (AMACR) is associated with ERG expression and with adverse clinical outcome in patients with localized prostate cancer. Tumour biology. 2016; 37:12287-12299.

32. Yamoah K, Johnson MH, Choeurng V, Faisal FA, Yousefi K, Haddad Z, Ross AE, Alshalafa M, Den R, Lal P, Feldman M, Dicker AP, Klein EA, et al. Novel Biomarker Signature That May Predict Aggressive Disease in African American Men With Prostate Cancer. J Clin Oncol. 2015; 33:2789-96.

33. Farrell J, Young D, Chen Y, Cullen J, Rosner IL, Kagan J, Srivastava S, McLeod DG, Sesterhenn IA, Srivastava S, Petrovics G. Predominance of ERG-negative high-grade prostate cancers in African American men. Mol Clin Oncol. 2014; 2:982-86.

34. Saini S. PSA and beyond: alternative prostate cancer biomarkers. Cell Oncol (Dordr). 2016; 39:97-106.

35. Gaudreau PO, Stagg J, Soulières D, Saad F. The Present and Future of Biomarkers in Prostate Cancer: Proteomics, Genomics, and Immunology Advancements. Biomark Cancer. 2016; 8:15-33.

36. Moschini M, Spahn M, Mattei A, Cheville J, Karnes RJ. Incorporation of tissue-based genomic biomarkers into localized prostate cancer clinics. BMC Med. 2016; 14:67.

37. Beretov J, Wasinger VC, Millar EK, Schwartz P, Graham $\mathrm{PH}, \mathrm{Li}$ Y. Proteomic Analysis of Urine to Identify Breast Cancer Biomarker Candidates Using a Label-Free LC-MS/ MS Approach. PLoS One. 2015; 10:e0141876.

38. Xing X, Huang Y, Wang S, Chi M, Zeng Y, Chen L, Li L, Zeng J, Lin M, Han X, Liu J, Liu X. Dataset for the quantitative proteomics analysis of the primary hepatocellular carcinoma with single and multiple lesions. Data Brief. 2015; 5:226-40.

39. Matta A, Ralhan R, DeSouza LV, Siu KW. Mass spectrometry-based clinical proteomics: head-and-neck cancer biomarkers and drug-targets discovery. Mass Spectrom Rev. 2010; 29:945-61.

40. Hudler P, Kocevar N, Komel R. Proteomic approaches in biomarker discovery: new perspectives in cancer diagnostics. ScientificWorldJournal. 2014; 2014:260348.

41. Bañez LL, Srivastava S, Moul JW. Proteomics in prostate 
cancer. Curr Opin Urol. 2005; 15:151-56.

42. Fredolini C, Liotta LA, Petricoin EF. Application of proteomic technologies for prostate cancer detection, prognosis, and tailored therapy. Crit Rev Clin Lab Sci. 2010; 47:125-38.

43. Larkin SE, Zeidan B, Taylor MG, Bickers B, Al-Ruwaili J, Aukim-Hastie C, Townsend PA. Proteomics in prostate cancer biomarker discovery. Expert Rev Proteomics. 2010; 7:93-102.

44. Ornstein DK, Tyson DR. Proteomics for the identification of new prostate cancer biomarkers. Urol Oncol. 2006; 24:231-36.

45. Davalieva K, Polenakovic M. Proteomics in diagnosis of prostate cancer. Pril (Makedon Akad Nauk Umet Odd Med Nauki). 2015; 36:5-36.

46. Downes MR, Byrne JC, Dunn MJ, Fitzpatrick JM, Watson RW, Pennington SR. Application of proteomic strategies to the identification of urinary biomarkers for prostate cancer: a review. Biomarkers. 2006; 11:406-416.

47. Pin E, Fredolini C, Petricoin EF 3rd. The role of proteomics in prostate cancer research: biomarker discovery and validation. Clin Biochem. 2013; 46:524-38.

48. Davalieva K, Kiprijanovska S, Komina S, Petrusevska G, Zografska NC, Polenakovic M. Proteomics analysis of urine reveals acute phase response proteins as candidate diagnostic biomarkers for prostate cancer. Proteome Sci. 2015; 13:2.

49. Lin JF, Xu J, Tian HY, Gao X, Chen QX, Gu Q, Xu GJ, Song JD, Zhao FK. Identification of candidate prostate cancer biomarkers in prostate needle biopsy specimens using proteomic analysis. Int J Cancer. 2007; 121:2596605.

50. Rizzardi AE, Rosener NK, Koopmeiners JS, Isaksson Vogel R, Metzger GJ, Forster CL, Marston LO, Tiffany JR, McCarthy JB, Turley EA, Warlick CA, Henriksen JC, Schmechel SC. Evaluation of protein biomarkers of prostate cancer aggressiveness. BMC Cancer. 2014; 14:244.

51. Shipitsin M, Small C, Choudhury S, Giladi E, Friedlander S, Nardone J, Hussain S, Hurley AD, Ernst C, Huang YE, Chang H, Nifong TP, Rimm DL, et al. Identification of proteomic biomarkers predicting prostate cancer aggressiveness and lethality despite biopsy-sampling error. Br J Cancer. 2014; 111:1201-12.

52. Al-Ruwaili JA, Larkin SE, Zeidan BA, Taylor MG, Adra $\mathrm{CN}$, Aukim-Hastie CL, Townsend PA. Discovery of serum protein biomarkers for prostate cancer progression by proteomic analysis. Cancer Genomics Proteomics. 2010; 7:93-103.

53. Uhlén M, Fagerberg L, Hallström BM, Lindskog C, Oksvold P, Mardinoglu A, Sivertsson Å, Kampf C, Sjöstedt E, Asplund A, Olsson I, Edlund K, Lundberg E, et al. Proteomics. Tissue-based map of the human proteome. Science. 2015; 347:1260419.

54. Rho JH, Roehrl MH, Wang JY. Tissue proteomics reveals differential and compartment-specific expression of the homologs transgelin and transgelin-2 in lung adenocarcinoma and its stroma. J Proteome Res. 2009; 8:5610-18.

55. Chen CL, Chung T, Wu CC, Ng KF, Yu JS, Tsai CH, Chang YS, Liang Y, Tsui KH, Chen YT. Comparative Tissue Proteomics of Microdissected Specimens Reveals Novel Candidate Biomarkers of Bladder Cancer. Mol Cell Proteomics. 2015; 14:2466-78.

56. Shah P, Zhang B, Choi C, Yang S, Zhou J, Harlan R, Tian Y, Zhang Z, Chan DW, Zhang H. Tissue proteomics using chemical immobilization and mass spectrometry. Anal Biochem. 2015; 469:27-33.

57. Chandramouli K, Qian PY. Proteomics: challenges, techniques and possibilities to overcome biological sample complexity. Human genomics and proteomics. 2009; 2009.

58. $\mathrm{Hu} \mathrm{S}$, Loo JA, Wong DT. Human body fluid proteome analysis. Proteomics. 2006; 6:6326-53.

59. Nannini M, Astolfi A, Urbini M, Biasco G, Pantaleo MA. Liquid biopsy in gastrointestinal stromal tumors: a novel approach. J Transl Med. 2014; 12:210.

60. Siravegna G, Bardelli A. Genotyping cell-free tumor DNA in the blood to detect residual disease and drug resistance. Genome Biol. 2014; 15:449.

61. Alix-Panabières C, Pantel K. Real-time liquid biopsy: circulating tumor cells versus circulating tumor DNA. Ann Transl Med. 2013; 1:18.

62. Karachaliou N, Mayo-de-Las-Casas C, Molina-Vila MA, Rosell R. Real-time liquid biopsies become a reality in cancer treatment. Ann Transl Med. 2015; 3:36.

63. Heitzer E, Auer M, Ulz P, Geigl JB, Speicher MR. Circulating tumor cells and DNA as liquid biopsies. Genome Med. 2013; 5:73.

64. Galletti G, Portella L, Tagawa ST, Kirby BJ, Giannakakou $\mathrm{P}$, Nanus DM. Circulating tumor cells in prostate cancer diagnosis and monitoring: an appraisal of clinical potential. Mol Diagn Ther. 2014; 18:389-402.

65. Marrinucci D, Bethel K, Kolatkar A, Luttgen MS, Malchiodi M, Baehring F, Voigt K, Lazar D, Nieva J, Bazhenova L, Ko AH, Korn WM, Schram E, et al. Fluid biopsy in patients with metastatic prostate, pancreatic and breast cancers. Phys Biol. 2012; 9:016003.

66. Brock G, Castellanos-Rizaldos E, Hu L, Coticchia C, Skog J. Liquid biopsy for cancer screening, patient stratification and monitoring. Transl Cancer Res. 2015; 4:280-90.

67. Sobhani K. Urine proteomic analysis: use of twodimensional gel electrophoresis, isotope coded affinity tags, and capillary electrophoresis. Methods Mol Biol. 2010; 641:325-46.

68. Decramer S, Gonzalez de Peredo A, Breuil B, Mischak H, Monsarrat B, Bascands JL, Schanstra JP. Urine in clinical proteomics. Mol Cell Proteomics. 2008; 7:1850-62.

69. Pisitkun T, Johnstone R, Knepper MA. Discovery of urinary biomarkers. Mol Cell Proteomics. 2006; 5:1760-71. 
70. Drucker E, Krapfenbauer K. Pitfalls and limitations in translation from biomarker discovery to clinical utility in predictive and personalised medicine. EPMA J. 2013; 4:7.

71. Novelli G, Ciccacci C, Borgiani P, Papaluca Amati M, Abadie E. Genetic tests and genomic biomarkers: regulation, qualification and validation. Clin Cases Miner Bone Metab. 2008; 5:149-54.

72. Henry NL, Hayes DF. Cancer biomarkers. Mol Oncol. 2012; 6:140-46.

73. Diamandis EP. The failure of protein cancer biomarkers to reach the clinic: why, and what can be done to address the problem? BMC Med. 2012; 10:87.

74. Galasko D, Golde TE. Biomarkers for Alzheimer's disease in plasma, serum and blood - conceptual and practical problems. Alzheimers Res Ther. 2013; 5:10.

75. Goldknopp IL, Sheta E, Bryson J, Folsom B, Wilson C, Duty J, Yen A, Appel S. Blood serum biomarkers for differential diagnosis of Parkinson's disease. FASEB J. 2006; 20:A64-64.

76. Jesneck JL, Mukherjee S, Yurkovetsky Z, Clyde M, Marks JR, Lokshin AE, Lo JY. Do serum biomarkers really measure breast cancer? BMC Cancer. 2009; 9:164.

77. Allen RE, Rogozinska E, Cleverly K, Aquilina J, Thangaratinam S. Abnormal blood biomarkers in early pregnancy are associated with preeclampsia: a metaanalysis. Eur J Obstet Gynecol Reprod Biol. 2014; 182:194-201.

78. Reuschenbach M, von Knebel Doeberitz M, Wentzensen N. A systematic review of humoral immune responses against tumor antigens. Cancer Immunol Immunother. 2009; 58:1535-44.

79. Thakur A, Littrup P, Paul EN, Adam B, Heilbrun LK, Lum LG. Induction of specific cellular and humoral responses against renal cell carcinoma after combination therapy with cryoablation and granulocyte-macrophage colony stimulating factor: a pilot study. J Immunother. 2011; 34:457-67.

80. Ullenhag GJ, Frödin JE, Jeddi-Tehrani M, Strigård K, Eriksson E, Samanci A, Choudhury A, Nilsson B, Rossmann ED, Mosolits S, Mellstedt H. Durable carcinoembryonic antigen (CEA)-specific humoral and cellular immune responses in colorectal carcinoma patients vaccinated with recombinant CEA and granulocyte/ macrophage colony-stimulating factor. Clin Cancer Res. 2004; 10:3273-81.

81. Michils A, Yernault JC, Noel E, Gossart B, Servais G, Duchateau J. Abnormal humoral immune response to mucosal antigenic stimulation in patients with lung cancer. Cancer. 1992; 69:2252-57.

82. Fosså A, Berner A, Fosså SD, Hernes E, Gaudernack G, Smeland EB. NY-ESO-1 protein expression and humoral immune responses in prostate cancer. Prostate. 2004; 59:440-47.

83. Sreekumar A, Laxman B, Rhodes DR, Bhagavathula S,
Harwood J, Giacherio D, Ghosh D, Sanda MG, Rubin MA, Chinnaiyan AM. Humoral immune response to alphamethylacyl-CoA racemase and prostate cancer. J Natl Cancer Inst. 2004; 96:834-43.

84. Reis BS, Jungbluth AA, Frosina D, Holz M, Ritter E, Nakayama E, Ishida T, Obata Y, Carver B, Scher H, Scardino PT, Slovin S, Subudhi SK, et al. Prostate cancer progression correlates with increased humoral immune response to a human endogenous retrovirus GAG protein. Clin Cancer Res. 2013; 19:6112-25.

85. Pontes ER, Matos LC, da Silva EA, Xavier LS, Diaz BL, Small IA, Reis EM, Verjovski-Almeida S, Barcinski MA, Gimba ER. Auto-antibodies in prostate cancer: humoral immune response to antigenic determinants coded by the differentially expressed transcripts FLJ23438 and VAMP3. Prostate. 2006; 66:1463-73.

86. Todorova K, Ignatova I, Tchakarov S, Altankova I, Zoubak S, Kyurkchiev S, Mincheff M. Humoral immune response in prostate cancer patients after immunization with gene-based vaccines that encode for a protein that is proteasomally degraded. Cancer Immun. 2005; 5:1.

87. Jiang FN, He HC, Zhang YQ, Yang DL, Huang JH, Zhu YX, Mo RJ, Chen G, Yang SB, Chen YR, Zhong WD, Zhou WL. An integrative proteomics and interaction networkbased classifier for prostate cancer diagnosis. PLoS One. 2013; 8:e63941.

88. Turay D, Khan S, Diaz Osterman CJ, Curtis MP, Khaira B, Neidigh JW, Mirshahidi S, Casiano CA, Wall NR. Proteomic Profiling of Serum-Derived Exosomes from Ethnically Diverse Prostate Cancer Patients. Cancer Invest. 2016; 34:1-11.

89. Adeola HA, Soares NC, Paccez JD, Kaestner L, Blackburn JM, Zerbini LF. Discovery of novel candidate urinary protein biomarkers for prostate cancer in a multiethnic cohort of South African patients via label-free mass spectrometry. Proteomics Clin Appl. 2015; 9:597-609.

90. Adeola HA, Calder B, Soares NC, Kaestner L, Blackburn JM, Zerbini LF. In silico verification and parallel reaction monitoring prevalidation of potential prostate cancer biomarkers. Future Oncol. 2016; 12:43-57.

91. Adeola HA, Smith M, Kaestner L, Blackburn JM, Zerbini LF. Novel potential serological prostate cancer biomarkers using CT100+ cancer antigen microarray platform in a multi-cultural South African cohort. Oncotarget. 2016; 7:13945-64. doi: 10.18632/oncotarget.7359.

92. Jeelani S, Reddy RC, Maheswaran T, Asokan GS, Dany A, Anand B. Theranostics: A treasured tailor for tomorrow. J Pharm Bioallied Sci. 2014; 6:S6-8.

93. Lee DY, Li KC. Molecular theranostics: a primer for the imaging professional. AJR Am J Roentgenol. 2011; 197:318-24.

94. Netto GJ, Epstein JI. Theranostic and prognostic biomarkers: genomic applications in urological malignancies. Pathology. 2010; 42:384-94. 
95. Geisler C, Gaisa NT, Pfister D, Fuessel S, Kristiansen G, Braunschweig T, Gostek S, Beine B, Diehl HC, Jackson $\mathrm{AM}$, Borchers $\mathrm{CH}$, Heidenreich A, Meyer HE, et al. Identification and validation of potential new biomarkers for prostate cancer diagnosis and prognosis using 2D-DIGE and MS. Biomed Res Int. 2015; 2015:454256.

96. Hunter DJ, Losina E, Guermazi A, Burstein D, Lassere MN, Kraus V. A pathway and approach to biomarker validation and qualification for osteoarthritis clinical trials. Curr Drug Targets. 2010; 11:536-45.

97. Pepe MS, Etzioni R, Feng Z, Potter JD, Thompson ML, Thornquist M, Winget M, Yasui Y. Phases of biomarker development for early detection of cancer. J Natl Cancer Inst. 2001; 93:1054-61.

98. Hernández J, Thompson IM. Prostate-specific antigen: a review of the validation of the most commonly used cancer biomarker. Cancer. 2004; 101:894-904.

99. Mandrekar SJ, Sargent DJ. Clinical trial designs for predictive biomarker validation: one size does not fit all. J Biopharm Stat. 2009; 19:530-42.

100. Trock BJ. Validation of surrogate endpoint biomarkers in prostate cancer chemoprevention trials. Urology. 2001; 57: 241-47.

101. Brown JE, Sim S. Evolving role of bone biomarkers in castration-resistant prostate cancer. Neoplasia. 2010; 12:685-96.

102. Brenner DE, Normolle DP. Biomarkers for cancer risk, early detection, and prognosis: the validation conundrum. Cancer Epidemiol Biomarkers Prev. 2007; 16:1918-20.

103. Knaul FM, Atun R, Farmer P, Frenk J. Seizing the opportunity to close the cancer divide. Lancet. 2013; 381:2238-39.

104. Roberts R. Bridging the urological divide. Infect Agent Cancer. 2011; 6:S4.

105. Odedina FT, Dagne G, Pressey S, Odedina O, Emanuel F, Scrivens J, Reams RR, Adams A, Larose-Pierre M. Prostate cancer health and cultural beliefs of black men: The Florida Prostate Cancer Disparity Project. Infect Agent Cancer. 2011; 6:S10.

106. Gakunga R, Parkin DM, African Cancer Registry Network. Cancer registries in Africa 2014: A survey of operational features and uses in cancer control planning. International journal of cancer. 2015; 137:2045-2052.

107. Agalliu I, Adebiyi AO, Lounsbury DW, Popoola O, Jinadu K, Amodu O, Paul S, Adedimeji A, Asuzu C, Asuzu M, Ogunbiyi OJ, Rohan T, Shittu OB. The feasibility of epidemiological research on prostate cancer in African men in Ibadan, Nigeria. BMC Public Health. 2015; 15:425.

108. Olapade-Olaopa EO, Obamuyide HA, Yisa GT. Management of advanced prostate cancer in Africa. Can J Urol. 2008; 15:3890-98.

109. Sfanos KS, De Marzo AM. Prostate cancer and inflammation: the evidence. Histopathology. 2012; 60:199215 .
110. Huang WY, Hayes R, Pfeiffer R, Viscidi RP, Lee FK, Wang YF, Reding D, Whitby D, Papp JR, Rabkin CS. Sexually transmissible infections and prostate cancer risk. Cancer Epidemiol Biomarkers Prev. 2008; 17:2374-81.

111. Adewole I, Martin DN, Williams MJ, Adebamowo C, Bhatia K, Berling C, Casper C, Elshamy K, Elzawawy A, Lawlor RT, Legood R, Mbulaiteye SM, Odedina FT, et al. Building capacity for sustainable research programmes for cancer in Africa. Nat Rev Clin Oncol. 2014; 11:251-59.

112. Shapiro LJ. Human genome project. West J Med. 1993; 158:181.

113. Weinstein JN, Collisson EA, Mills GB, Shaw KR, Ozenberger BA, Ellrott K, Shmulevich I, Sander C, Stuart JM, Cancer Genome Atlas Research Network. The Cancer Genome Atlas Pan-Cancer analysis project. Nat Genet. 2013; 45:1113-20.

114. Legrain P, Aebersold R, Archakov A, Bairoch A, Bala K, Beretta L, Bergeron J, Borchers CH, Corthals GL, Costello CE, Deutsch EW, Domon B, Hancock W, et al. The human proteome project: current state and future direction. Mol Cell Proteomics. 2011; 10:M111 009993.

115. Ponomarenko E, Baranova A, Lisitsa A, Albar JP, Archakov A. The chromosome-centric human proteome project at FEBS Congress. Proteomics. 2014; 14:147-52.

116. Vaught J, Rogers J, Myers K, Lim MD, Lockhart N, Moore H, Sawyer S, Furman JL, Compton C. An NCI perspective on creating sustainable biospecimen resources. Journal of the National Cancer Institute Monographs. 2011; 2011:1-7.

117. Bledsoe MJ, Grizzle WE. Use of human specimens in research: the evolving United States regulatory, policy, and scientific landscape. Diagn Histopathol (Oxf). 2013; 19:322-30.

118. Vaught JB, Henderson MK, Compton CC. Biospecimens and biorepositories: from afterthought to science. Cancer Epidemiol Biomarkers Prev. 2012; 21:253-55.

119. Ollier W, Sprosen T, Peakman T. UK Biobank: from concept to reality. Pharmacogenomics. 2005; 6:639-46.

120. Rush A, Christiansen JH, Farrell JP, Goode SM, Scott RJ, Spring KJ, Byrne JA. Biobank classification in an Australian setting. Biopreserv Biobank. 2015; 13:212-18.

121. Gasmelseed N, Elsir AA, Deblasio P, Biunno I. SubSaharan centralized biorepository for genetic and genomic research. Sci Total Environ. 2012; 423:210-13.

122. Staunton C, Moodley K. Challenges in biobank governance in Sub-Saharan Africa. BMC Med Ethics. 2013; 14:35.

123. de Vries J, Abayomi A, Brandful J, Littler K, Madden E, Marshall P, Ouwe Missi Oukem-Boyer O, Seeley J. A perpetual source of DNA or something really different: ethical issues in the creation of cell lines for African genomics research. BMC Med Ethics. 2014; 15:60.

124. Abayomi A, Christoffels A, Grewal R, Karam LA, Rossouw C, Staunton C, Swanepoel C, van Rooyen B. Challenges of biobanking in South Africa to facilitate indigenous research in an environment burdened with human immunodeficiency 
virus, tuberculosis, and emerging noncommunicable diseases. Biopreserv Biobank. 2013; 11:347-54.

125. Gulley JL, Drake CG. Immunotherapy for prostate cancer: recent advances, lessons learned, and areas for further research. Clin Cancer Res. 2011; 17:3884-91.

126. Scher HI, Morris MJ, Larson S, Heller G. Validation and clinical utility of prostate cancer biomarkers. Nat Rev Clin Oncol. 2013; 10:225-34.

127. Howat WJ, Lewis A, Jones P, Kampf C, Pontén F, van der Loos CM, Gray N, Womack C, Warford A. Antibody validation of immunohistochemistry for biomarker discovery: recommendations of a consortium of academic and pharmaceutical based histopathology researchers. Methods. 2014; 70:34-38.

128. Li Y, Vongsangnak W, Chen L, Shen B. Integrative analysis reveals disease-associated genes and biomarkers for prostate cancer progression. BMC Med Genomics. 2014; 7:S3.

129. Pentyala S, Whyard T, Pentyala S, Muller J, Pfail J, Parmar S, Helguero CG, Khan S. Prostate cancer markers: an update. Biomed Rep. 2016; 4:263-68.

130. Schlomm T, Chun FK, Erbersdobler A. From gene to clinic: TMA-based clinical validation of molecular markers in prostate cancer. Methods Mol Biol. 2010; 664:177-89.
131. Erho N, Crisan A, Vergara IA, Mitra AP, Ghadessi M, Buerki C, Bergstralh EJ, Kollmeyer T, Fink S, Haddad Z, Zimmermann B, Sierocinski T, Ballman KV, et al. Discovery and validation of a prostate cancer genomic classifier that predicts early metastasis following radical prostatectomy. PLoS One. 2013; 8:e66855.

132. Danila DC, Anand A, Schultz N, Heller G, Wan M, Sung CC, Dai C, Khanin R, Fleisher M, Lilja H, Scher HI. Analytic and clinical validation of a prostate cancerenhanced messenger RNA detection assay in whole blood as a prognostic biomarker for survival. Eur Urol. 2014; 65:1191-97.

133. Sartori DA, Chan DW. Biomarkers in prostate cancer: what's new? Curr Opin Oncol. 2014; 26:259-64.

134. Canfield SE, Kibel AS, Kemeter MJ, Febbo PG, Lawrence HJ, Moul JW. A guide for clinicians in the evaluation of emerging molecular diagnostics for newly diagnosed prostate cancer. Rev Urol. 2014; 16:172-80.

135. Roobol MJ, Haese A, Bjartell A. Tumour markers in prostate cancer III: biomarkers in urine. Acta Oncol. 2011; 50:85-89. 